\title{
Politics, Economy and Society in Contemporary China
}




\section{Politics, Economy and Society in Contemporary China}

Bill Brugger

and

Stephen Reglar

MACMILLAN 
(C) Bill Brugger and Stephen Reglar 1994

All rights reserved. No reproduction, copy or transmission of this publication may be made without written permission.

No paragraph of this publication may be reproduced, copied or transmitted save with written permission or in accordance with the provisions of the Copyright, Designs and Patents Act 1988, or under the terms of any licence permitting limited copying issued by the Copyright Licensing Agency, 90 Tottenham Court Road, London W1P 9HE.

Any person who does any unauthorised act in relation to this publication may be liable to criminal prosecution and civil claims for damages.

First published 1994 by

THE MACMILLAN PRESS LTD

Houndmills, Basingstoke, Hampshire RG21 2XS

and London

Companies and representatives

throughout the world

ISBN 978-0-333-60194-5

ISBN 978-1-349-23329-8 (eBook)

DOI 10.1007/978-1-349-23329-8

A catalogue record for this book is available from the British Library.

Copy-edited and typeset by Povey-Edmondson

Okehampton and Rochdale, England

$\begin{array}{lllllllll}10 & 9 & 8 & 7 & 6 & 5 & 4 & 3 & 2\end{array}$

$\begin{array}{llllllll}05 & 04 & 03 & 02 & 01 & 00 & 99 & 98\end{array}$ 


\section{Contents}

Acknowledgements

vii

Introduction

Part 1 Overview

1 China Under Mao

2 China After Mao

48

Part 2 Themes

3 State and Countryside

4 State, Enterprise and Town

5 Law and Policing

6 Intellectuals and Struggles

7 Family and Gender Relations.

8 Minority Nationalities

305

Bibliography

Index 


\section{Acknowledgements}

The authors have drawn on some parts of earlier works and have reproduced a few passages verbatim (Brugger $1981 \mathrm{a}$ and b; Brugger 1971). In all cases we are grateful to the publishers (International Thompson Publishing Services and UNESCO) who have given their permission for direct quotation. Thanks also are due to Professor Ted Wolfers and the staff of the Department of History and Politics at the University of Wollongong for making time available for one of the authors. We are, of course, grateful for the contributions from students at the Flinders University of South Australia to whom a draft text was directed. For constructive comments, thanks are due also to Tony Saich, Yvonne Corcoran-Nantes and Noel Tracy. For editorial work, thanks go to David Jolley. For much wider support, particular thanks go to Suzanne Brugger and Rosemary Reglar. 